\title{
Morphological and genetic divergence between Mediterranean and Caribbean populations of Madracis pharensis (Heller 1868) (Scleractinia, Pocilloporidae): too much for one species?
}

\author{
FRANCESCA BENZONI ${ }^{1,2 *}$, ROBERTO ARRIGONI ${ }^{3,}$, MICHAEL L . BERUMEN $^{3}$, MARCO $^{2}$
} TAVIANI ${ }^{4,5,6}$, PIM BONGAERTS $^{7,8} \&$ PEDRO R. FRADE ${ }^{8,9}$

${ }^{1}$ Department of Biotechnology and Biosciences, University of Milano-Bicocca, Piazza della Scienza, 2, 20126 Milan, Italy

${ }^{2}$ Institut de Recherche pour le Développement, UMR9220 ENTROPIE, 101 Promenade Roger Laroque, BP A5, 98848 Nouméa Cedex, New Caledonia

${ }^{3}$ Red Sea Research Center, Division of Biological and Environmental Science and Engineering, King Abdullah University of Science and Technology, Thuwal 23955-6900, Saudi Arabia

${ }^{4}$ Institute of Marine Sciences - National Research Council, (ISMAR-CNR), Via Gobetti 101, 40129 Bologna, Italy

${ }^{5}$ Biology Department, Woods Hole Oceanographic Institution, 266 Woods Hole Road, Woods Hole, MA 02543, USA

${ }^{6}$ Stazione Zoologica Anton Dohrn, Villa Comunale, 80121 Naples, Italy

${ }^{7}$ Global Change Institute, The University of Queensland, Brisbane QLD 4072, Australia

${ }^{8}$ CARMABI, Piscaderabaai z/n, PO Box 2090, Willemstad, Curaçao

${ }^{9}$ Department of Limnology and Bio-Oceanography, University of Vienna, Althanstrasse 14, 1090 Vienna, Austria

* corresponding author

\begin{abstract}
The colonial stony coral genus Madracis is cosmopolitan, lives in shallow and deep water habitats, and includes zooxanthellate, azooxanthellate and facultative symbiotic species. One of its species, Madracis pharensis, has been recorded from the Mediterranean and East Atlantic, where it forms small knobby and facultative zooxanthellate colonies (also named M. pharensis f. pharensis), and from the tropical Caribbean, where it also occurs in a massive and zooxanthellate form (named M. pharensis $f$. luciphila by some). These two forms have been previously found to host different Symbiodinium species. In this study, species boundaries and phylogenetic relationships between these two Madracis pharensis forms (from the Mediterranean Sea and the Caribbean), M. senaria, and the Indo-west Pacific M. kirbyi were analyzed through an integrated systematics approach, including corallite dimensions, micromorphology and two molecular markers (ITS and ATP8). Significant genetic and morphological differences were found between all the examined Madracis species, and between M. pharensis from the Mediterranean Sea and M. pharensis f. luciphila from the Caribbean in particular. Based on these results, the latter does not represent a
\end{abstract}


zooxanthellate ecomorph of the former but a different species. Its identity remains to be ascertained and its relationship with the Caribbean $M$. decactis, with which it bears morphologic resemblance, must be investigated in further studies. Overall, the presence of cryptic Madracis species in the Easter and Central Atlantic remains to be evaluated.

Keywords Madracis senaria, Madracis kirbyi, rDNA, ATP8, corallite diameter 


\section{Introduction}

The genus Madracis Milne Edwards and Haime, 1849 is found throughout the tropics but also lives in temperate waters in shallow and deep habitats (Fricke \& Hottinger 1983; Cairns 1984, 1991, 1999, 2000; Veron \& Pichon 1976; Veron 2000; Santodomingo et al. 2007; Neves \& Johnsson 2009). It includes colonial species forming encrusting, nodular, branching or massive coralla, which are either zooxanthellate, azooxanthellate or facultative symbionts thus occurring in zooxanthellate and azooxanthellate forms (Wells 1973a, b; Zibrowius 1980; Cairns et al. 1999, 2000; Frade et al. 2008a).

Madracis has been included in the Pocilloporidae by several authors (Wells 1956; Veron \& Pichon 1976; Zibrowius 1980; Sheer \& Pillai 1983; Cairns 1991, 1994, 1999, 2000; Veron 1986; Sheppard \& Sheppard, 1991; Neves \& Johnsson, 2009) until Veron (2000) moved it in the Astrocoeniidae Koby 1890 based on the presence of a "style-like columella and neatly arranged solid septa". Since, several studies based on different nuclear and mitochondrial makers confirmed the opinion of previous authors that Madracis is closely related to Pocillopora and allies rather than to the astrocoeniid Stephanocoenia Milne Edwards \& Haime 1848 (Romano \& Cairns 2000; Fukami et al. 2008; Kitahara et al. 2010; Stolarski et al. 2011; Huang 2012; Keshavmurthy et al. 2013; Arrigoni et al. 2017).

Madracis is characterized by a hexameral, octameral or decameral septal symmetry, and a styliform columella (Cairns \& Kitahara 2012). Like in the other Pocilloporidae Gray, 1842, corallites are small (usually less than $2 \mathrm{~mm}$ in diameter) and typically present a limited number of characters that can be used to identify species and delineate species boundaries (Veron \& Pichon 1976; Reyes Bonilla et al. 1995; Stefani et al. 2011; Schmidt-Roach et al. 2014). Veron \& Pichon (1976) remarked that the genus Madracis "badly needs a revision on a world-wide scale, in the light of extensive and reliable ecological data". To date, no formal revision has been undertaken. However, much progress has been made in the current knowledge on the biology, ecology and systematics of the shallow water hermatypic Madracis species from the Caribbean (Diekmann et al. 2001; Vermeij \& Bak 2002a, b; Vermeij et al. 2001, 2002, 2003a, b, c, 2004; Kaandorp et al. 2003, 2005; Vermeij \& Sandin 2006; Frade et al. 2008a, b, c, 2010; Filatov et al. 2013) and Brazil (Muramatsu \& Lang da Silveira 2008; Neves \& Johnsson 2009; Capel et al. 2012). Outside of the Western Atlantic, the studies on deep and shallow water Madracis species deal mainly with their taxonomy and occurrence (Veron \& Pichon 1976; Cairns 1991, 1994, 1999; Cairns \& Zibrowius 1997; Veron 2000; Zibrowius et al. 2017), less frequently with aspects of their biology and ecology (Laborel \& Vacelet 1958; Zibrowius 1980; Morri et al. 2000; Özalp \& Alparslan 2015).

Madracis pharensis (Heller, 1868) was described from Hvarski Kanal, Croatia, in the Adriatic. The holotype appears to be lost (Zibrowius 1980) and in the species original description two drawings (Plate 1, Figs. 1-2) show a typically nodular colony and the expanded polyps, but no detail of the corallites. However, Zibrowius (1980) provided good illustrations of the species morphology based on his extensive reference collection now deposited at the National Museum of Natural History (MNHN) in Paris. Madracis pharensis forms small clumps or encrusting colonies (Figs. 1a, b) often found in caves and overhangs (Morri et al. 2000) and has two cycles of ten septa (S1 > S2) with well-formed paliform lobes (Zibrowius 1980). It is found at 
various localities in the Mediterranean and in the Eastern Atlantic (Madeira, Canary, Cap Verde, and Azores islands) (Zibrowius 1980; Cairns 2000; Morri et al. 2000; Gerovasileiou et al. 2015; Özalp \& Alparslan 2015). Laborel (1960) first reported this species from Brazil, and Goreau \& Wells (1967) found a "cavernicolous" M. pharensis in Jamaica, thus extending the known species range to the Western Atlantic where it was later recorded also from various localities in the Caribbean and Bahamas, Gulf of Mexico, and Gulf of Campeche (Cairns 2000).

Wells (1973a) in a study of the Scleractinia from Jamaica, distinguished two forms of M. pharensis, one he defined lucifugous and ahermatypic with encrusting and nodular growth form, M. pharensis f. pharensis (Heller, 1868), and the other one luciphilous and hermatypic with laminar or encrusting growth form, $M$. pharensis f. luciphila Wells, 1973. Admittedly, the author did not look into detail at the corallite scale differences between the two forms, as he stated "attention is focused on the characters of the corallum". Some authors (Cairns 2000; Cairns et al. 2009) still separate M. pharensis luciphila and M. pharensis pharensis following Wells' (1973a) distinction between the hermatypic and the ahermatypic forms in the Caribbean. However, most authors have abandoned such distinction and referred to the zooxanthellate form (Figs. 1b, c) as M. pharensis in their works (Diekmann et al. 2001; Vermeij \& Bak 2002b; Vermeij et al. 2004; Frade et al. 2008a, b, c, 2010; Neves \& Johnsson 2009) although they did start separating different colour morphs having differences in their ecology and reproductive biology (Vermeij et al. 2004; Frade et al. 2008b, 2010).

Wells (1973a) stated that M. pharensis f. luciphila "may be a distinct species, but the morphology of the skeletal structures appears to be identical”. Doubts have been also expressed by Zibrowius (1980) on the actual identity of the Caribbean and Brazilian specimens he could examine. Later, Fenner (1993) on the basis of his observations of living corals at different localities in the tropical Western Atlantic (Mexico, Martinique, Saint Lucia, the Cayman Islands, and Honduras) concluded that M. pharensis in this region is actually a form, or ecomorph, of the morphologically plastic zooxanthellate Madracis decactis (Lyman, 1859), a conclusion challenged by the overlapping light usage strategies of the two species (Vermeij \& Bak 2002a). Diekmann et al. (2001) included two specimens of M. pharensis from the Mediterranean in their genetic analyses of Caribbean shallow water Madracis. In their phylogenetic reconstruction based on a nuclear ribosomal marker (nrDNA: ITS region), the specimens from the Mediterranean, chosen as an outgroup, were only distantly related to the Caribbean specimens which formed a paraphyletic species complex with M. decactis, M. formosa Wells, 1973, and M. carmabi Vermeij, Diekmann \& Bak, 2003. Although later Frade et al. (2010) using a mitochondrial (mtDNA: NAD5) and two nuclear (nDNA: ATPSa and SRP54) intron markers confirmed that the species boundaries between all Caribbean species except $M$. senaria Wells, 1973 are semi-permeable, they did not include material from the Mediterranean. Furthermore, significant genetic differences were found between shallow and deep water populations of the examined $M$. pharensis from the Caribbean (with threshold at ca. $25 \mathrm{~m}$ depth), a pattern recently confirmed by another mitochondrial marker (mtDNA: ATP8, Bongaerts et al. 2015). Interestingly, this depth-related genetic divergence in $M$. pharensis strictly matches that of the dominant endosymbiont lineages harbored by this 
species, with Symbiodinium type B7 associating with the shallow M. pharensis population and type B15 associating with the deep population (Frade et al. 2010). Such genetic partitioning of host and symbiont populations is not unique to Madracis, and highlights the potential role of depth-related processes in the evolution of brooding corals and their associated Symbiodinium (Frade et al. 2010, Bongaerts et al. 2013). To date, the genetic and morphological boundaries between M. pharensis f. luciphila and M. pharensis f. pharensis in the Caribbean, and between these two forms and the Mediterranean and West Atlantic $M$. pharensis remain unexplored.

In the Indo-Pacific, M. kirbyi Veron \& Pichon, 1976 is the only known shallow water, zooxanthellate and reef dwelling Madracis species (Figs. 1g, h). First described from Australia, this species is found from the Red Sea to the central Pacific (Veron 2000). In their original description, Veron \& Pichon (1976) remarked on the morphological similarities between this species and $M$. pharensis from the Mediterranean and $M$. decactis, yet they separated it from the congeners in reason of a much-reduced second cycle of septa. However, the degree of development of the second cycle of septa appears to be a rather variable character, questioned by some authors (e.g. Zlatarski \& Estalella 1980). The species boundaries between M. pharensis and $M$. kirbyi remain unstudied, being the sequences of the latter species are still unavailable to date. In this study, specimens of the hermatypic and zooxanthellate morph of M. pharensis (Figs. 1c, d) and M. senaria (Figs. 1e, f) from the Caribbean previously analyzed by Frade et al. (2010), M. pharensis from the Mediterranean (Figs. 1a, b), and M. kirbyi from the Indo-Pacific (Figs. 1g, h) are examined for the first time through an integrated approach combining two different markers (ITS and ATP8) and micro-morphological and morphometric data. Genetic and micromorphological differences, or lack thereof, between the typical $M$. pharensis from the Mediterranean and the Caribbean material are addressed. Moreover, species boundaries between M. pharensis, M. senaria, and M. kirbyi are investigated. A detailed description of the species' micromorphology is provided for the first time and its relevance from a systematic standpoint in the genus Madracis is discussed in an evolutionary context.

\section{Methods}

Sampling, examined collections and identification of the specimens

A total of 54 Madracis specimens were examined in this study (Table 1). Specimens were collected during SCUBA diving at various localities in the Mediterranean, on Curaçao (former Netherland Antilles) in the Southern Caribbean, and in the Indo-Pacific between 2 and $30 \mathrm{~m}$ depth (Fig. 2, Table 1). One specimen of Madracis pharensis was sampled from 30-60 m depth in Kotor Bay, Montenegro during the CROatianMontenegrin Marine ecosystems (CROMA) cruise of RV Urania in February 2014.. After collection, corals were tagged and a fragment preserved in $95 \%$ ethanol for further molecular analyses. The corallum was then bleached in sodium hypochlorite, rinsed with freshwater, and air-dried for identification and morphological analyses. Corals were identified examining the type material and following Zibrowius (1980), Zlatarski \& Estalella (1980) and Veron \& Pichon (1976). The extensive collection of Mediterranean and Eastern Atlantic corals by Dr H. Zibrowius deposited at the MNHN was examined and specimens of $M$. pharensis were 
observed at the stereo microscope. Fragments of five specimens were loaned to the first author for further analyses at the Scanning Electronic Microscope (SEM).

In order to avoid confusion and repetitions of the geographic origin of the examined specimens we henceforth refer to the non symbiotic Mediterranean and Eastern Atlantic material as M. pharensis, and to the zooxanthellate form from the Caribbean as M. pharensis f. luciphila. The azooxanthellate Caribbean form of M. pharensis (=M. pharensis f. pharensis), was not investigated in this study as material could not be retrieved.

\section{DNA extraction, amplification, and sequence analyses}

Total genomic DNA was extracted from coral tissue using DNeasy Blood and Tissue Kit (Qiagen Inc., Valencia, CA, USA), following the manufacturer's protocol. Polymerase chain reaction (PCR) amplification was carried out for two molecular markers, a $~ 1400$ bp portion of the mitochondrial DNA spanning a section of the 3' end of NAD5 gene, the entire trnW and the putative ATP8 genes, the entire intergenic spacer between ATP8 and COI genes, and a section of the 5' end of COI gene (hereafter ATP8) (Chen et al. 2008; Flot et al. 2008a) and a 600 bp portion of the nuclear rRNA including the 3' end of the 18S rRNA, the entire ITS1, 5.8S, and ITS2, and the 5' end of the 28S rRNA (hereafter ITS region). These two molecular markers have proved to be powerful in the definition of species boundaries in the other pocilloporid genera Pocillopora (Flot et al. 2008a; Schmidt-Roach et al. 2012; Pinzon et al. 2013), Seriatopora (Flot et al. 2008b) and Stylophora (Flot et al. 2011; Stefani et al. 2011; Klueter \& Andreakis 2013). The ATP8 locus was amplified for a total of 39 samples, the ITS region for 54. The ATP8 locus was amplified using the primers FNAD5.2deg and RCOI3 (Flot et al. 2008a) in a $25 \mu$ PCR volume containing 1X PCR buffer, 1.5 $\mathrm{mM} \mathrm{MgCl}_{2}, 0.2 \mu \mathrm{M}$ for both of each primer, $0.1 \mathrm{mM}$ of each dNTP, and $2 \mathrm{U}$ of Taq polymerase. Thermal cycling conditions were $94^{\circ}$ for $2 \mathrm{~min} ; 35$ cycles of $94^{\circ}$ for $30 \mathrm{sec}, 53^{\circ}$ for $1 \mathrm{~min}$, and $72^{\circ}$ for $1 \mathrm{~min}$; and $72^{\circ}$ for 2 min. ITS region was amplified using the primers A18S (Takabayashi et al. 1998) and ITS4 (White et al. 1990), following the protocol proposed by Benzoni et al. (2011). All PCR products were purified with Illustra ExoStar (GE Healthcare, Buckinghamshire, United Kingdom) and directly sequenced in forward and reverse directions using an ABI 3130xl Genetic Analyzer (Applied Biosystems, Carlsbad, California). Sequences obtained in this study were deposited in EMBL, and accession numbers are listed in Table 1. Chromatograms were viewed, edited and assembled using CodonCode Aligner 5.0.2 (CodonCode Corporation, Dedham, MA, USA) and manually checked using BioEdit 7.2.5 (Hall 1999). Alignments of the two separated molecular loci were carried out using the E-INS-I option in MAFFT 7.164 (Katoh et al. 2002; Katoh \& Standley 2013) under default parameters. Sequence alignments were converted into the Roehl file format using DnaSP 5.10.1 (Librado \& Rozas 2009), removing invariable sites and not considering sites with gaps/missing. Relationships among haplotypes were reconstructed using NETWORK 4.612 (http://www.fluxus-engineering.com), based on the median-joining algorithm (Bandelt et al. 1999). Intraand interspecific pair-wise distances (uncorrected $p$-distances) within and between the four examined Madracis species were calculated in MEGA 6 (Tamura et al. 2013). 


\section{Morphological analyses}

Scleractinian coral samples were analyzed both at macro- and micromorphological level, using light microscopy (Leica M80 microscope) and SEM, respectively. In total, specimens 40 were studied and measured, 11 of M. pharensis, 10 of M. pharensis f. luciphila, 12 of M. kirby, and 7 of M. senaria. Corallum fragments size varied among species with nodular fragments of the colonies of $M$. pharensis being the smallest examined and reaching a maximum of $2 \mathrm{~cm}$ in length and width (Fig. 1). For imaging of corallite micromorphology at the scanning electron microscope (SEM), fragments of specimens were grinded, mounted on stubs using silver glue, sputter-coated with conductive gold film and examined using a Vega Tescan Scanning Electron Microscopy at University of Milano-Bicocca.

Coral skeletons for corallite measures were imaged through a Leica M80 microscope equipped with a Leica IC80HD camera at the same magnification to obtain images of $14 \times 10.5 \mathrm{~mm}$ of the corallum surface. The Analyzing Digital Images tool was used to take measurements of the inter columella distance (ID) defined as the linear distance between the centre of the columella and two adjacent corallites, and of the calice diameter (CD) (Fig. 3). ID and CD were measured on five corallites for each specimen. Measures were taken between and within haphazardly selected corallites without any evidence of extracalicinal budding. In case of coralla with nodular growth forms, only corallites found on the sides and at least $5 \mathrm{~mm}$ from the top were considered. Variables were log-transformed, tested for normality (Shapiro-Wilk's W-test) and homogeneity of variance (Levene's test), then subjected to an analysis of variance. Turkey's test for unequal sample size (Spjotvoll \& Stoline 1973) was used for post hoc comparisons of means. Alpha values were adjusted using the Bonferroni correction for multiple tests taking into account the average variable correlation (Simes 1986). For each character, the specimen mean from the five replicates was calculated.

\section{Results}

\section{Molecular results}

Sequence lengths of ATP8 ranged from 1155 (in M. pharensis) to 1275 bp (in M. kirbyi), and those of ITS region ranged from 599 to $603 \mathrm{bp}$. Relationships among haplotypes of the four examined Madracis species are shown in Figs. 4a, b for the separated mitochondrial and nuclear molecular loci, respectively. A total of 38 ATP8 sequences for the four examined Madracis species were obtained and used for the haplotype network analysis. A total of nine haplotypes were identified from the ATP8 alignment: a single haplotype specific of M. kirbyi, a single haplotype specific of M. pharensis luciphila, three closely related haplotypes of $M$. senaria separated by up to four mutations, and four closely related haplotypes of $M$. pharensis separated by up to three mutations (Fig. 4a). No haplotypes are shared between the four lineages that are thus genetically isolated. Madracis pharensis f. luciphila, M. senaria, and M. pharensis varied among each other by 31-35 base changes, while M. kirbyi differed from the other three Madracis by at least 102 base changes. Intraspecific genetic distance ( $p$-distance) ranged from 0 to 0.19 , while pair-wise comparison of genetic distances between species were considerable higher. The average distance of $M$. 
pharensis from $M$. pharensis f. luciphila ( $3.21 \pm 0.51$ )was comparable to those between $M$. senaria and $M$. pharensis (3.04 \pm 0.51$)$, and between M. senaria and M. pharensis f. luciphila (3.49 \pm 0.55$)$ (Table 4). Alignment of the ITS region was conducted on a total of 63 sequences: 31 sequences newly obtained in the present study and the remaining ones downloaded from GenBank (in particular, two sequences of $M$. pharensis, 18 of $M$. pharensis f. luciphila, and 12 of M. senaria). As detected also for the mitochondrial region, the network showed no shared haplotype among the four lineages, being, therefore, genetically separated. It revealed four main clusters of haplotypes that matched with the four examined Madracis lineages (Fig. 4b). Haplotypes of $M$. kirbyi were clearly distant from the other three lineages and separated by 11-19 mutation events. A minimum of eight base changes differentiated Madracis pharensis and M. pharensis f. luciphila, while at least seven mutations occurred between M. senaria and M. pharensis and a minimum of five mutations separated M. senaria and M. pharensis $\mathrm{f}$. luciphila. The mean genetic distance between M. pharensis and M. pharensis f. luciphila $(1.81 \pm 0.4)$, was similar to the genetic distances between $M$. senaria and M. pharensis $(1.73 \pm 0.37)$ and between $M$. senaria and M. pharensis f. luciphila $(1.71 \pm 0.39)($ Table 5).

\section{Morphological results}

The examined specimens of M. pharensis have round to polygonal corallites (Figs. 5a, e) with a cerioid or sub-plocoid arrangement (Fig. 5a). Average CD is $1.66 \mathrm{~mm}( \pm 0.22)$ (Table 2). Septal arrangement is decameral ( $\mathrm{S} 1=10)$ with $\mathrm{S} 2$ shorter than $\mathrm{S} 1$ (Figs. 5e, i). The top margin of the $\mathrm{S} 1$ is slightly exsert or flush, with a coenosteum ornamentation. Finely ornamented septal lobes are found at the inner end of the septa before fusing with the columella (Figs. 5e, i). A deep notch is found between the inner part of the corallite wall and the distal end of the septa (arrow in Fig. 5i). S1 sides with blunt spines all over the surface (Fig. 5m). The well developed styliform columella sits relatively deep in the fossa, with a wide base (Fig. 5e), pointed (Fig. 5i), and circular to oval in section (Figs. 5e, i). Columellae of adjacent corallites are on average $2.01 \mathrm{~mm}( \pm 0.27)$ apart. Coenosteum generally very reduced and composed by a series of juxtaposed granules corresponding to the tips of trabeculae (Figs.5i, m).

The skeletons of $M$. pharensis f. luciphila from Frade et al. (2010) included in our analyses have round corallites (Figs. 5b, f) with a plocoid arrangement (Figs. 5b). Average CD is $1.25 \mathrm{~mm}( \pm 0.12)$ (Table 2). Septal arrangement is decameral ( $\mathrm{S} 1=10)$ (Fig. 5f). S2 are shorter than $\mathrm{S} 1$ being in some specimens extremely reduced and visible only at the SEM as lobes alternating with S1 (Figs. 5f, j), while in others is more developed and visible (Fig. 3). The top margin of the S1 is exsert to the coenosteum, being also higher than the coenosteum ornamentation (arrow in Fig. 5j). Finely ornamented septal lobes are found at the inner end of the septa before they fuse with the columella (Figs. 3, 45f, j). S1 sides with blunt spines all over the surface (Fig. 5n). A styliform columella sits relatively deep in the fossa and is well developed, with a wide base (Fig. 5e), pointed (Fig. 4i), and circular in section (Figs. 5e, i). Columellae of adjacent corallites are on average $1.84 \mathrm{~mm}( \pm 0.28)$ apart. Coenosteum well developed, compact (Fig. 3) or presenting pits between the corallite wall and the coenosteum ornamentation (Figs. 5 b, f, n) which is composed of medium sized 
granules (smaller than those observed in M. pharensis) (Figs. 5j, n) mostly arranged in lines forming a reticule separating adjacent corallites (Fig. 3).

The coralla of M. senaria from Frade et al. (2010), included in our analyses, have round corallites with a plocoid arrangement (Figs. 5c, g). Average CD is $1.45 \mathrm{~mm}( \pm 0.12)$ (Table 2). As described by Wells (1973b), S1 = 10, but septa are dimorphic. In fact, six protosepta (S1P, Figs. 5g, k) and four metasepta (S1M, Figs. 5g, k) can be distinguished, with S1M thinner and shorter than S1P. The top margin of the S1P is exsert with respect to the coenosteum (arrow in Fig. 5k) and higher than the S1M margin. Septal lobes at the inner end of the septa were not observed in the examined specimens (Fig. 5k). Septal side ornamentation present on S1P towards the outer end of the septa where they are thicker, reduced or absent on S1P (Fig. 5k). The styliform columella sits relatively deep in the fossa and is well developed and with a variably wide base, rounded at the top (Fig. 5k), and circular to oval in section (Figs. $5 \mathrm{~g}$, k). Columellae of adjacent corallites are on average $2.31 \mathrm{~mm}( \pm 0.36)$ apart. Coenosteum well developed, compact (Fig. 5c). Coenosteum ornamentation is composed of small sized granules (Fig. 5o) which can be well formed or very reduced. The examined specimens of $M$. kirbyi have round to polygonal corallites with a cerioid or sub-plocoid arrangement depending of the specimen (Fig. 5d; Figs. 164, 165 in Veron \& Pichon 1976). Average CD is $1.45 \mathrm{~mm}( \pm 0.18)$ (Table 2). Septal arrangement is decameral $(\mathrm{S} 1=10)$ with reduced to extremely reduced $\mathrm{S} 2$ (Fig. 5h). The top margin of the S1 is slightly exsert or flush with the coenosteum ornamentation. Finely ornamented septal lobes are found at the inner end of the septa before they fuse with the columella (Fig. 51). A notch is found between the inner part of the corallite wall and the distal end of the septa (arrow in Fig. 51) resulting in a lobe similar to that observed in $M$. pharensis although in this species lobes are more pronounced. S1 sides with blunt spines all over the surface (Fig. 51). The styliform columella sits relatively deep in the fossa and is well developed, with a wide base (Figs. 5h, 1), rounded, and circular to oval in section (Figs. 5h, 1). Columellae of adjacent corallites are on average $1.91 \mathrm{~mm}( \pm 0.32)$ apart. Coenosteum generally well formed, ornamentation composed by a series of large (Fig. 5p) or medium (Fig. 5h) sized granules forming bounding ridges shared by adjacent corallites (Fig. 5d) (Veron \& Pichon 1976).

Statistically significant differences in CD were found between $M$. pharensis, which has the largest average $\mathrm{CD}$ among the examined species, M. pharensis f. luciphila (smallest CD) and M. senaria. Statistically significant differences in CD were also found between M. pharensis f. luciphila and M. senaria and M. kirbyi (Table 3). No statistically significant differences in calice dimensions were found between M. pharensis and M. kirbyi, and M. senaria (Table 3). Statistically significant differences in ID were found between $M$. senaria, which has the largest ID among the examined species, and M. pharensis (smallest ID), M. pharensis f. luciphila, and $M$. kirbyi (Table 3). No statistically significant differences ID were found between $M$. pharensis and M. pharensis f. luciphila, or M. kirbyi, nor between M. pharensis f. luciphila and M. kirbyi (Table 3).

\section{Discussion}

Genetic and morphological boundaries between the examined species 
Significant genetic and morphological differences were found among the examined Madracis species in general, and between M. pharensis and M. pharensis f. luciphila in particular. All the examined species presented a decameral arrangement of the septa $(\mathrm{S} 1=10 ; \mathrm{S} 2<\mathrm{S} 1$ or extremely reduced) with the case of $M$. senaria presenting dimorphism of $\mathrm{S} 1(\mathrm{~S} 1 \mathrm{P}=6 ; \mathrm{S} 1 \mathrm{M}=4)$ (Fig. 5). Overall, the development of $\mathrm{S} 2$ varied in all the examined species, being always extremely reduced in $M$. senaria but variable in the other species. According to Cairns (2000) and to Neves \& Johnsson (2009), M. pharensis specimens from southwestern Atlantic have 12 septa, $6 \mathrm{~S} 1$ and $6 \mathrm{~S} 2$. Although we agree with these authors that "septal number may be an unreliable character if considered exclusively" (Neves \& Johnsson 2009), none of the specimens we examined had 12 septa and we are aware of no description or illustration of $M$. pharensis with such arrangement. Moreover, the figures of M. pharensis in Cairns (2000: Figs. 36-41) show a typical decameral arrangement of the septa. In fact, the author kindly acknowledged a lapsus calami in the text of his publication (S.D. Cairns pers. comm.).

Our results show that the examined Mediterranean specimens of $M$. pharensis and the Caribbean $M$. pharensis f. luciphila are genetically distinct (Tables 4-5). Moreover, although the average inter corallite distance is not significantly different between the two supposed morphs of the same species, corallites in $M$. pharensis are statistically significantly larger than in M. pharensis f. luciphila (Fig. 6; Table 3). These remarkable differences, highlighted in this study for the first time, suggest that M. pharensis f. luciphila is not simply a different morph of $M$. pharensis, but that it is a distinct species and that the two can be distinguished based on their morphology, genetics and ecology. Therefore, the doubts expressed by previous authors (Wells 1973a; Zibrowius 1980) on the actual identity of the Caribbean and Brazilian specimens of $M$. pharensis are confirmed by our findings. However, two points remain to be clarified before any formal taxonomic action can be undertaken. Firstly, it is needed to verify if, as suggested by Fenner (1993), the zooxanthellate M. pharensis f. luciphila which has been called M. pharensis in the Caribbean and in Brazil is actually a form, or ecomorph, of the morphologically plastic and zooxanthellate Madracis decactis. In fact, Frade et al. (2010) showed that the genetic boundaries between these species are semi-permeable. Secondly, the genetic and morphologic boundaries between the azooxanthellate and sciaphilous M. pharensis from the Caribbean and the forms examined in this study need to be investigated. The difference in size between the zooxanthellate (larger) and azooxanthellate (smaller) Caribbean forms were already remarked by Cairns (2000) who also noted that the former has more widely spaced corallites than the latter.

There is recognized ecophenotypic plasticity at both colony and corallite level in Madracis (Todd 2008). However, Filatov et al. (2013) argued that morphological characteristics at the colony level in addition to corallite morphology, genetic and ecological information, are in particular useful to delineate different coral species in the genus. They focused on Caribbean species characterized by a branching growth form and did not include either form of M. pharensis. Although we did not include measures of the corallum shape in our morphological analyses, all the coralla of the examined M. pharensis specimens were from knob-shaped and/or encrusting colonies, while all the examined specimens of $M$. pharensis f. luciphila were from typically encrusting or massive coralla. 
Our results showed that $M$. pharensis and $M$. kirbyi are genetically distinct. However, no statistically significant difference in corallite diameter or inter columellar distance was found between these two species. In the original description of M. kirbyi, Veron \& Pichon (1976) remarked that this species has a muchreduced second cycle of septa compared with that of the Mediterranean specimens of M. pharensis, but that the two species seem related. The degree of development of the second cycle of septa considered by some authors as an informative character seems actually rather variable intraspecifically as also remarked by Zlatarski \& Estalella (1980) in their description of M. decactis. Morphological analyses at the SEM showed, however, differences in columellar morphology between the two species. In M. pharensis the columella is wider at the base (Fig. 5e) than in M. kirbyi (Fig. 5h) and its tip is pointed (Fig. 5i), while in the latter it is rounded (Fig. 5l). Moreover, in several of the examined M. kirbyi specimens the septa reaching the columella form a pattern of radiating ridges on its surface (Fig. 5h). Schmidt-Roach et al. (2014) suggested that in the genus Pocillopora the shape of the columella could be a reliable character to tell species apart despite a remarkable reduction and morphologic variability of the septa. Our results indicate that the columella could be also an informative morphological character in in Madracis, suggesting that this feature should be taken into account in future studies addressing species level differences in other pocilloporids as well. Madracis senaria is morphologically and genetically a distinct species being the only one among the Caribbean species examined by Frade et al. (2010) for which clear genetic boundaries were evidenced. Our results confirm this finding, showing that this species is also genetically distinct from M. pharensis and M. kirbyi. Despite significant genetic differences between $M$. kirbyi and $M$. senaria, and although corallites are more distant in the latter than in the former, these two species have similar corallite diameter. The peculiar dimorphism of $\mathrm{S} 1(\mathrm{~S} 1 \mathrm{P}=6 ; \mathrm{S} 1 \mathrm{M}=4)$ (Fig. 5) in Madracis senaria, however, allows to readily tell these two species apart from all the other described species in the genus.

Difference in hosted endosymbiont species between M. pharensis and M. pharensis $f$. luciphila In addition to the genetic and morphological differences discussed above, M. pharensis and M. pharensis $\mathrm{f}$. luciphila differ also in some ecological traits. In the temperate Mediterranean and Eastern Atlantic, zooxanthellate colonies of the facultative symbiotic species (Cairns et al. 1999) host the cold-loving Symbiodinium pysgmophilum (LaJeunesse et al. 2012) harbored by subtropical and temperate corals, previously named type B2. However, all specimens from the Caribbean examined by Frade et al. (2008a, b, c) hosted Symbiodinium B7 type, while the colonies below $25 \mathrm{~m}$ hosted the B15 type instead. This genotype dominates the deeper symbiont populations associated with M. pharensis f. luciphila all the way down to the host's lower limit of distribution of $>90 \mathrm{~m}$ depth (Bongaerts et al. 2015). Such observed niche partitioning relates to the physiological capabilities of the symbionts involved (Frade et al. 2008b) and matches the evolutionary split between shallow and deep $M$. pharensis f. luciphila lineages, suggesting depth-related environmental gradients as driving factors to disruptive selection and the evolution of corals (Frade et al. 2010, Bongaerts et al. 2013). 
The occurrence of M. pharensis outside the Mediterranean and the Eastern Atlantic

In addition to the aforementioned records of M. pharensis in the Western Atlantic, an azooxanthellate form of Madracis named M. sp. cf M. pharensis has been recorded in the Indo-Pacific in the Philippines and Fiji (Cairns \& Zibrowius 1997), the Galapagos (Wells 1983, Cairns 1991, Hickman 2008), and in the Guf of California, Mexico (Reyes Bonilla et al. 1995; Cairns \& Zibrowius 1997)(;;;;. Not much is known about this form which has never been analyzed genetically. Reyes Bonilla et al. (1995) suggested that skeletal differences among M. pharensis and Madracis sp. cf M. pharensis "are important and consistent enough that they may represent two different species" mainly based on the extreme reduction of the secondary septa in the Pacific form (e.g. Hickman 2008:24 SEM figure). Our results confirm the suspicions expressed by some authors (see Wells 1973a; Zibrowius 1980; Fenner 1993) that the Caribbean zooxanthellate and hermatypic form previously named M. pharensis (Diekmann et al. 2001; Vermeij \& Bak 2002b; Vermeij et al. 2004; Frade et al. 2008a, b, c, 2010) and M. pharensis f. luciphila (Wells 1973a; Cairns 2000; Cairns et al. 2009) is not the same species as M. pharensis from the Mediterranean (Heller 1868; Laborel \& Vacelet 1958; Zibrowius 1980; Gerovasileiou et al. 2015). However, the azooxanthellate Caribbean form M. pharensis f. pharensis was not investigated in this study. Nevertheless, it cannot be ignored that this sciaphilous azooxanthellate form with smaller encrusting to nodular coralla (Cairns 2000) is morphologically and genetically the same as M. pharensis from the Mediterranean and the Azores. Thus, further analyses including M. pharensis f. pharensis are needed to clarify the status of this form and, most of all, the actual geographic distribution of the typical M. pharensis. Moreover, the species boundaries between M. pharensis f. luciphila and the other Caribbean species examined by Diekmann et al. (2001) and Frade et al. (2010), namely M. decactis, M. formosa, M. mirabilis (= Madracis auretenra Locke, Weil \& Coates, 2007) and $M$. carmabi, need to be analyzed using ATP8 as a marker together with detailed micromorphological tools and will be addressed in a paper in preparation.

\section{Conclusions}

The results presented in this paper indicate that $M$. pharensis from the Mediterranean Sea and the form cM. pharensis f. luciphila found in the Caribbean are two genetically and morphologically different species. Moreover, Madracis kirbyi, examined for the first time in this study through an integrated systematics approach, and $M$. senaria are valid species genetically and morphologically distinct from the formers. However, whether M. pharensis f. luciphila is an undescribed species or a morph of M. decactis remains to be ascertained. Also, the possibility that $M$. pharensis f. luciphila is a complex of species with host depth partitioning and genetic segregation of its symbionts can not be excluded. Moreover, the identity of the azooxanthellate Caribbean form of M. pharensis remains unresolved. These issues need to be addressed on a broad morphological and genetic comparative study for the whole genus Madracis including material from a wide depth range. 


\section{Acknowledgements}

The authors are indebted with A Caragnano (IRD), S Montano (UNIMIB), V Macic (Institute of Marine Biology, Kotor), and F Cardone (University of Bari) for providing specimens of $M$. pharensis from different localities in Italy, and to A Andouche (MNHN) for the loan of samples for SEM analysis. Samples loaned from the MNHN belong to the extensive collection of $\mathrm{H}$ Zibrowius and included material collected during the MEDOR (http://dx.doi.org/10.17600/67162211 ) and Bioaçores campaigns onboard the RV Jean Charcot. A Winkelhagen, F Vermeulen, N Englebert and J Faria are acknowledged for their help during collection of Caribbean specimens. We are grateful to captain, crew and colleagues onboard RV Urania during cruise CROMA. This work is part of EU F.P. VII Projects COCONET, (contract no. 287844), and EVER-EST (contract no. 674907), DG Environment programme IDEM (grant agreement No 11.0661 /2017/750680/SUB/EN V.C2), and the Flag Project Ritmare (Ricerca Italiana per il Mare) project, and is ISMAR-Bologna scientific contribution number 1863. Material from New Caledonia was sampled during the HYDROPRONY (http://dx.doi.org/10.17600/11100060), CORALCAL4

(http://dx.doi.org/10.17600/12100060) campaigns onboard the RV Alis and during the first author MLD granted from IRD under the direction of C. Payri. For sampling during the TARA OCEANS expedition we thank the commitment of the following people and sponsors: CNRS (in particular Groupement de Recherche GDR3280), European Molecular Biology Laboratory (EMBL), Genoscope/CEAthe French Government 'Investissements d'Avenir' programmes OCEANOMICS (ANR-11-BTBR-0008) and FRANCE GENOMIQUE (ANR-10-INBS-09-08), Agence Nationale de la Recherche, and European Union FP7 (MicroB3/No.287589), We also thank the support and commitment of agnès b. and Etienne Bourgois, the Veolia Environment Foundation, Region Bretagne, Lorient Agglomeration, World Courier, Illumina, the Eléctricité de France (EDF) Foundation, Fondation pour la recherche sur la biodiversité (FRB), the Foundation Prince Albert II de Monaco, the Tara Foundation, its schooner and teams. We are also grateful to the French Ministry of Foreign Affairs for supporting the expedition and to the countries who graciously granted sampling permissions. Tara Oceans would not exist without continuous support from 23 institutes (http:// http://oceans.taraexpeditions.org/en/m/science/labs-involved/). The authors further declare that all data reported herein are fully and freely available from the date of publication, with no restrictions, and that all of the samples, analyses, publications, and ownership of data are free from legal entanglement or restriction of any sort by the various nations whose waters the Tara Oceans expedition sampled in. This article is contribution number ZZZ of Tara Oceans. The Madang expedition specimens were obtained during the "Our Planet Reviewed" Papua Niugini expedition (http://dx.doi.org/10.17600/12100070) organized by Muséum National d'Histoire Naturelle (MNHN), Pro Natura International (PNI), Institut de Recherche pour le Développement (IRD) and University of Papua New Guinea (UPNG), Principal Investigators P. Bouchet, C. Payri and S. Samadi. The organizers acknowledge funding from the Total Foundation, Prince Albert II of Monaco Foundation, Fondation EDF, Stavros Niarchos Foundation and Entrepose Contracting, and in-kind support from the Divine Word University (DWU). The expedition operated under a permit delivered by the Papua New Guinea Department of Environment and Conservation. We are also grateful to EPA Socotra, E 
Dutrieux (Creocean), CH Chaineau (Total SA), R Hirst, M Abdul Aziz (YLNG), and M Pichon (MTQ) for allowing and supporting research in Yemen. This work is supported by King Abdullah University of Science and Technology's Red Sea Research Center (CCF. grant FCC/1/1973-07 to M.L.Berumen). The authors are grateful to S.D. Cairns and two anonymous reviewers for their suggestions on the manuscript.

\section{References}

Arrigoni, R., Vacherie, B., Benzoni, F., Stefani, F., Karsenti, E., Jaillon, O., Not, F., Nunes, F., Payri, C., Wincker, P. \& Barbe V. (2017) A new sequence dataset of SSU rRNA gene for Scleractinia and its phylogenetic and ecological applications. Molecular Ecology Resources, 17, 1054-1071.

Bandelt, H.J., Forster, P. \& Röhl, A. (1999) Median-joining networks for inferring intraspecific phylogenies. Molecular Biology and Evolution, 16, 37-48.

Benzoni, F., Arrigoni, R., Stefani, F. \& Pichon, M. (2011) Phylogeny of the coral genus Plesiastrea (Cnidaria, Scleractinia). Contributions to Zoology, 80, 231-248.

Bongaerts, P., Frade, P.R., Ogier, J.J., Hay, K.B., van Bleijswijk, J., Englebert, N., Vermeij, M.J.A., Bak, R.P.M., Visser, P.M. \& Hoegh-Guldberg, O. (2013) Sharing the slope: depth partitioning of agariciid corals and associated Symbiodinium across shallow and mesophotic habitats (2-60 m) on a Caribbean reef. BMC Evolutionary Biology, 13, 205.

Bongaerts, P., Frade, P.R., Hay, K.B., Englebert, N., Latijnhouwers, K., Bak, R.P.M., Vermeij, M.J.H. \& Hoegh-Guldberg, O. (2014) The lower mesophotic zone of a Southern Caribbean reef: limited by temperature rather than light? Scientific Reports, 5, 7652.

Cairns, S.D. (1991) A revision of the ahermatypic Scleractinia of the Galápagos and Cocos Islands. Smithsonian Contributions to Zoology, 504, 1-32.

Cairns, S.D. (1994) Scleractinia of the Temperate North Pacific. Smithsonian Contributions to Zoology $557: 1-150$

Cairns, S.D. (1999) Cnidaria Anthozoa: Deep-Water azooxanthellate Scleractinia from Vanuatu and Wallis and Futuna Islands. Annales du Muséum national d'histoire naturelle, 180, 31-167.

Cairns, S.D. (2000) A revision of the shallow-water azooxanthellate Scleractinia of the western Atlantic. Studies on the Natural History of the Caribbean Region, 75, 1-231.

Cairns, S.D., Jaap, W.C. \& Lang, J.C. (2009) Scleractinia (Cnidaria) of the Gulf of Mexico. In: Felder, D.L. \& Camp, D.K. (Eds) Gulf of Mexico-Origins, Waters, and Biota. Biodiversity. Texas A and M Press, College Station Texas USA, pp. 333-347.

Cairns, S.D., Hoeksema, B.W. \&Van Der Land, J. (1999) Appendix: List of extant stony corals. Atoll Research Bulletin, 459, 13-46.

Cairns, S.D. \& Kitahara, M. (2012) An illustrated key to the genera and subgenera of the recent azooxanthellate Scleractinia (Cnidaria, Anthozoa), with an attached glossary. ZooKeys, 227, 1-47.

Cairns, S.D. \& Zibrowius, H. (1997) Cnidaria, Anthozoa: azooxanthellate Scleractinia from the Philippine and Indonesian regions. Mémoires du Muséum d'histoire naturelle, 172, 27-243. 
Capel, K.C.C., Segal, B., Lindner, A. \& Bertuol, P. (2012) Corallith beds at the edge of the tropical South Atlantic. Coral Reefs, 31, 75.

Chen, C., Chiou, C.Y., Dai, C.F. \& Chen, C.A. (2008) Unique mitogenomic features in the scleractinian family Pocilloporidae (Scleractinia: Astrocoeniina). Marine Biotechnology, 10, 538-553.

Fenner, D. (1993) Species distinctions among several Caribbean stony corals. B Mar Scie 53:1099-1116

Filatov, M.V., Frade, P.R., Bak, R.P.M., Vermeij, M.J.A. \& Kaandorp, J.A. (2013) Comparison between colony morphology and molecular phylogeny in the Caribbean scleractinian coral genus Madracis. PLoS ONE, 8, e71287.

Flot, J.F., Magalon, H., Cruaud, C., Couloux, A., Tillier, S. (2008a) Patterns of genetic structure among Hawaiian corals of the genus Pocillopora yield clusters of individuals that are compatible with morphology. Comptes Rendus Biologies, 331, 239-247.

Flot, J.F., Licuanan, W.Y., Nakano, Y., Payri, C., Cruaud, C. \& Tillier, S. (2008b) Mitochondrial sequences of Seriatopora corals show little agreement with morphology and reveal the duplication of a tRNA gene near the control region. Coral Reefs, 27, 789-794.

Flot, J.F., Blanchot, J., Charpy, L., Cruaud, C., Licuanan, W.Y., Nakano, Y., Payri, C. \& Tillier, S. (2011) Incongruence between morphotypes and genetically delimited species in the coral genus Stylophora: phenotypic plasticity, morphological convergence, morphological stasis or interspecific hybridization? BMC Ecology, 4, 11-22.

Frade, P.R., De Jongh, F., Vermeulen, F., Van Bleijswijk, J. \& Bak, R.P.M. (2008a) Variation in symbiont distribution between closely related coral species over large depth ranges. Molecular Ecology, 17, 691-703.

Frade, P.R., Englebert, N., Faria, J., Visser, P.M. \& Bak, R.P.M. (2008b) Distribution and photobiology of Symbiodinium types in different light environments for three colour morphs of the coral Madracis pharensis: is there more to it than total irradiance? Coral Reefs, 27, 913-925.

Frade, P.R., Bongaerts, P., Winkelhagen, A.J.S., Tonk, L. \& Bak, R.P.M. (2008c) In situ photobiology of corals over large depth ranges: a multivariate analysis on the roles of environment, host, and algal symbiont. Limnology and Oceanography, 53, 2711-2723.

Frade, P.R., Reyes-Nivia, M.C., Faria, J., Kaandorp, J.A., Luttikhuizen, P.C. \& Bak, R.P.M. (2010) Semipermeable species boundaries in the coral genus Madracis: introgression in a brooding coral system. Molecular Phylogenetics and Evolution, 57, 1072-1090.

Fricke, H.W. \& Hottinger, L. (1983) Coral bioherms below the euphotic zone in the Red Sea. Marine Ecology Progress Series, 11, 113-117.

Fukami, H., Chen, C.A., Budd, A.F., Collins, A.G., Wallace, C.C., Chuang, Y.Y., Dai, C.F., Iwao, K., Sheppard, C.R.C. \& Knowlton, N. (2008) Mitochondrial and nuclear genes suggest that stony corals are monophyletic but most families of stony corals are not (Order Scleractinia, Class Anthozoa, Phylum Cnidaria). PLoS ONE, 3, e3222. 
Gerovasileiou, V., Chintiroglou, C.C., Vafidis, D., Koutsoubas, D., Sini, M., Dailianis, T., Issaris, Y., Akritopoulou, E., Dimarchopoulou, D. \& Voultsiadou, E. (2015) Census of biodiversity in marine caves of the eastern Mediterranean Sea. Mediterrean Marine Science, 16, 245-265.

Goreau, T.F. \& Wells, J.W. (1967) The shallow-water Scleractinia of Jamaica: revised list of speciesand their vertical distribution range. Bulletin of Marine Science, 17, 442-453.

Hall, T.A. (1999) BioEdit: a user-friendly biological sequence alignment editor and analysis program for Windows 95/98/NT. Nucleic Acids Symposium Series, 41, 95-98.

Heller, C. (1968) Die Zoophyten und Echinodermen des Adriatischen Meeres. Kaiserliche Koniglichen Zoologisch Botanisch Gesellschaft, Wien.

Huang, D. (2012) Threatened reef corals of the world. PLoS ONE, 7, e34459.

Hickman CP (2008) Corals and other radiates of Galapagos. Sugar Spring Press, Lexington, Virginia, USA Kaandorp, J.A., Koopman, E.A., Sloot, P.M.A., Bak, R.P.M., Vermeij, M.J.A. \& Lampmann, L.E.H. (2003) Simulation and analysis of flow patterns around the scleractinian coral Madracis mirabilis (Duchassaing and Michelotti). Philosophical Transactions of the Royal Society B: Biological Sciences, 358, 1551-1557.

Kaandorp, J.A., Sloot, P.M.A., Merks, R.M.H., Bak, R.P.M. \& Vermeij, M.J.A. (2005). Morphogenesis of the branching coral Madracis mirabilis. Proceedings of the Royal Society of London B: Biological Sciences, 272,127-133.

Katoh, K. \& Standley, D.M. (2013) MAFFT multiple sequence alignment software version 7: improvements in performance and usability. Molecular Biology and Evolution, 30, 772-780.

Katoh, K., Misawa, K., Kuma, K. \& Miyata, T. (2002) MAFFT: a novel method for rapid multiple sequence alignment based on fast Fourier transform. Nucleic Acids Research, 30, 3059-3066.

Keshavmurthy, S., Yang, S., Alamaru, A., Chuang, Y., Pichon, M., Obura, D., Fontana, S., De Palmas, S., Stefani, F., Benzoni, F., MacDonald, A., Noreen, A.M.E., Chen, C., Wallace, C.C., Moothien Pillay, R., Denis, V., Amri, A.Y., Reimer, J.D., Mezaki, T., Sheppard, C., Loya, Y., Abelson, A., Mohammed, M.S., Baker, A.C., Mostafavi, P.G., Suharsono, B.A. \& Chen, C.A. (2013) DNA barcoding reveals the coral "laboratory-rat", Stylophora pistillata encompasses multiple identities. Scientific Reports, 3, 1520.

Kitahara, M.V., Cairns, S.D., Stolarski, J., Blair, D. \& Miller, D.J. (2010) A comprehensive phylogenetic analysis of the Scleractinia (Cnidaria, Anthozoa) based on mitochondrial CO1 sequence data. PLoS ONE, 5, e11490.

Klueter, A. \& Andreakis, N. (2013) Assessing genetic diversity in the scleractinian coral Stylophora pistillata (Esper 1797) from the Central Great Barrier Reef and the Coral Sea. Systematics and Biodiversity, 11, 67-76.

Laborel, J. \& Vacelet, J. (1958) Étude des peuplements d'une grotte sous-marine du golfe de Marseille. Bulletin de l'Institut océanographique de Monaco, 1120, 1-20. 
Laborel, J. (1967) A revised list of Brazilian scleractinian corals and description of a new species. Postilla Yale Peabody Museum, 107, 1-14.

LaJeunesse, T.C., Parkinson, J.E. \& Reimer, J. (2012) A genetics-based description of Symbiodinium minutum sp. nov. and S. Psygmophilum sp. nov. (Dinophyceae), two dinoflagellates symbiotic with cnidaria. Journal of Phycology, 48, 1380-1391.

Librado, P. \& Rozas, J. (2009) DnaSP v5: A software for comprehensive analysis of DNA polymorphism data. Bioinformatics, 25, 1451-1452.

Lyman, T. (1859) On a new species of coral (Astraea decactis). Proceedings of the Boston Society of Natural History, 6, 260-263.

Locke, J.M., Weil, E. \& Coates, K.A. (2007) A newly documented species of Madracis (Scleractinia: Pocilloporidae) from the Caribbean. Proceedings of the Biological Society of Washington, 120, 214 226.

Milne Edwards, H. \& Haime, J. (1849) Mémoiresur les polypiers appartenant a la famille des Oculinides, au groupe intermediate des Pseudoastréides et a la famille des Fongides. Comptes Rendus Hebdomadaires Des Seances De l'Academie Des Sciences. Serie D: Sciences Naturelles, 29, 67-73.

Morri, C., Vafidis, D., Peirano, A., Chintiroglou, C.C. \& Bianchi, C.N. (2000) Anthozoa from a subtidal hydrothermal area of Milos Island (Aegean Sea), with notes on the construction potential of the scleractinian coral Madracis pharensis. Italian Journal of Zoology, 67, 319-325.

Muramatsu, D. \& Lang da Silveira, F. (2008) Gametogenesis in Madracis decactis Lyman, 1859 (Cnidaria, Scleractinia) from Ilha Grande Bay (Rio de Janeiro), southeastern Brazil. Brazilian Journal of Oceanography, 56, 297-305.

Neves, E. \& Johnsson, R. (2009) Taxonomic revision of the southwestern Atlantic Madracis and the description of Madracis fragilis n. sp. (Scleractinia: Pocilloporidae), a new coral species from Brazil. Scientia Marina, 73, 739-746.

Özalp, H.B., Alparslan, M. (2015) Distribution and morphology of the colonial scleractinian Madracis pharensis (Cnidaria, Anthozoa) in the Dardanelles (Marmara Sea, Turkey). Acta Zoologica Bulgarica, 67: 429-434.

Pinzon, J.H., Sampayo, E., Cox, E., Chauka, L.J., Chen, C.A., Voolstra, C.R. \& LaJeunesse, T.C. (2013) Blind to morphology: genetic identifies several widespread ecologically common species and few endemics among Indo-Pacific cauliflower corals (Pocillopora, Scleractinia). Journal of Biogeography, 40, 1595-1608.

Reyes Bonilla, H., Martinez Olguin, E. \& Reyna, G.A. (1995) First Record of Madracis sp. cf. M. pharensis (Heller, 1868) on Continental Eastern Pacific Shores. Bulletin of the Southern California Academy of Sciences, 94,172-175.

Romano, S.L. \& Cairns S.D. (2000) Molecular phylogenetic hypothesis for the evolution of scleractinian corals. Bulletin of Marine Science, 67, 1043-1068. 
Santodomingo, N., Reyes, J., Gracia, A., Martínez, A., Ojeda, G. \& García, C. (2007) Azooxanthellate Madracis coral communities off San Bernardo Islands (Colombian Caribbean). Bulletin of Marine Science, 81 (Suppl. 1), 273-287.

Scheer, G. \& Pillai, C.S.G. (1983) Report on the stony corals from the Red Sea. Zoologica, 131, 1-198. Schmidt-Roach, S., Lundgren, P., Miller, K.J., Gerlach, G., Noreen, A.M.E. \& Andreakis, N. (2012) Assessing hidden species diversity in the coral Pocillopora damicornis from Eastern Australia. Coral Reefs, 32, 161-172.

Schmidt-Roach, S., Miller, K.J., Lundgren, P. \& Andreakis, N. (2014) With eyes wide open: a revision of species within and closely related to the Pocillopora damicornis species complex (Scleractinia; Pocilloporidae) using morphology and genetics. Zoological Journal of the Linnean Society, 170, 133.

Sheppard, C.R.C. \& Sheppard, A.L.S. (1991) Corals and coral communities of Arabia. Fauna of Arabia, 12, $3-170$.

Simes, R.J. (1986) An improved Bonferroni procedure for multiple tests of significance. Biometrika, 73, $751-754$.

Spjotvoll, E. \& Stoline, M.R. (1973) An extension of the method of multiple comparisons to include the cases with unequal sample sizes. Journal of the American Statistical Association, 68, 975-978.

Stefani, F., Benzoni, F., Sung Yin, Y., Pichon, M., Galli, P. \& Chen, C.A. (2011) Comparison of morphological and genetic analyses reveal cryptic divergence and morphological plasticity in Stylophora (Cnidaria, Scleractinia). Coral Reefs, 30, 1033-1049.

Stolarski, J., Kitahara, M.V., Miller, D.J., Cairns, S.D., Mazur, M. \& Meibom, A. (2011) The ancient evolutionary origins of Scleractinia revealed by azooxanthellate corals. BMC Evolutionary Biology, 11,316

Takabayashi M., Carter D., Loh W. \& Hoegh-Guldberg O. (1998) A coral specific primer for PCR amplification of the internal transcribed spacer region in ribosomal DNA. Molecular Ecology, 7, 928-930.

Tamura, K., Stecher, G., Peterson, D., Filipski, A. \& Kumar, S. (2013) MEGA6: Molecular Evolutionary Genetics Analysis Version 6.0. Molecular Biology and Evolution, 30, 2725-2729.

Vermeij, M.J.A., Kaandorp JA, Bak, R.P.M. \& Lampmann, L.E.H. (2001) Three-dimensional morphological analysis of growth forms of Madracis mirabilis. In: Kaandorp, J.A. \& Kuebler, J. (Eds) The Algorithmic Beauty of Seaweeds, Sponges and Corals. Springer Verlag New York USA, 158 pp.

Vermeij, M.J.A., Delvoye, L. \& Bak, R.P.M. (2002) Fluorescence in the Caribbean coral genus Madracis. Photosynthetica, 40, 423-429.

Vermeij, M.J.A. \& Bak, R.P.M. (2002a) How are coral populations structured by light? Marine light regimes and the distribution of Madracis. Marine Ecology Progress Series, 233, 105-116.

Vermeij, M.J.A. \& Bak, R.P.M. (2002b) Corals on the move: rambling of Madracis pharensis polyps early after settlement. Coral Reefs, 21, 262-263. 
Vermeij, M.J.A., Diekmann, O.E. \& Bak, R.P.M. (2003a) A new species of Scleractinian coral (Cnidaria, Anthozoa), Madracis carmabi n. sp. from the Southern Caribbean. Bulletin of Marine Science, 73, 679-684.

Vermeij, M.J.A., Broker, K., Sampayo, E. \& Bak, R.P.M. (2003b) Planulae release in the Caribbean genus Madracis. Marine Ecology Progress Series, 247, 75-84.

Vermeij, M.J.A. \& Bak, R.P.M. (2003c) Species specific population structures of five closely related Madracis morphospecies along a depth gradient (5-60m) at a Caribbean coral reef. Bulletin of Marine Science,73, 725-744.

Vermeij, M.J.A., Broker, K., Sampayo, E. \& Bak, R.P.M. (2004) Gametogenesis in the Caribbean genus Madracis. Coral Reefs, 23, 206-214.

Vermeij, M.J.A. \& Sandin, S.A. (2006) Coral species complexes through space and time: an illustration of their dynamics using Madracis in the Caribbean. Proceedings of the 10th International Coral Reef Symposium, Okinawa, Japan, 116-121.

Veron, J.E.N. \& Pichon, M. (1976). Scleractinia of Eastern Australia. Monograph Series of the Australian Institute for Marine Science I.

Veron, J.E.N. (1986). Corals of Australia and the Indo-Pacific. Sydney, Angus \& Robertson.

Veron, J.E.N. (2000) Corals of the World. Australian Institute of Marine Science and CRR Queensland Australia.

Wells, J.W. (1956) Scleractinia. In: Moore, R.C. (Ed.) Treatise on invertebrate paleontology. Part F: Coelenterata. Lawrence, Kansas: Geological Society of America and University of Kansas Press, F328-F444.

Wells, J.W. (1973a) New and old scleractinian corals from Jamaica. Bulletin of Marine Science, 23,16-58.

Wells, J.W. (1973b) Two new hermatypic scleractinian corals from the West Indies. Bulletin of Marine Science, 23, 925-932.

Wells, J.W. (1983) Annotated list of the scleractinian corals of the Galapagos. In: Glynn, P.W. \& Wellington, G.M. (Eds) Corals and coral reefs of the Galapagos Islands. University of California Press Berkley and Los Angeles, pp. 211-291.

White, T.J., Bruns, T., Lee, S. \& Taylor, J. (1990) Amplification and direct sequencing of fungal ribosomal RNA genes for phylogenetics. In: Innis, M.A., Gelfand, D.H., Sninsky, J.J. \& White T.J. (Eds) PCR protocols. A guide to methods and application. Academic Press Inc. San Diego, pp. 315-322.

Zibrowius, H. (1980) Les scléractiniaires de la Méditerranée et de l'Atlantique nord-oriental. Mémoires de l'Institut Océanographique (Monaco), 11, 1-55.

Zibrowius, H., Wirtz, P., Nunes, F.L.D., Hoeksema, B.W. \& Benzoni, F. (2017) Shallow-water scleractinian corals of Ascension Island, Central South Atlantic. Journal of the Marine Biological Association of the United Kingdom, 97, 713-725.

Zlatarski, V.N. \& Martinez Estalella, N. (1982) Les Scléractiniaires de Cuba avec des données sur les organisms associés. Editions l’Académie Bulgare des Sciences Sofia, 471 pp. 


\section{Figure legends}

Fig. 1 In situ images of Madracis pharensis (a-b), M. pharensis f. luciphila (c-d), M. senaria (e-f), and M. kirbyi (g-h) showing corallum growth form and polyps; a azooxanthellate colony in a cave at $15 \mathrm{~m}$ (UNIMIB MD856, Sicily, Italy); b zooxanthellate colony with expanded polyps in an under-hang at 20m (UNIMIB MD846, Liguria, Italy); $\mathbf{c}$ a colony of the green morph (PF2006.936, Curaçao, Dutch Caribbean); d a colony of the brown morph (PF2006.699, Curaçao, Dutch Caribbean); e, f sub-massive colony; $\mathbf{g}$ encrusting colony at 15m (UNIMIB TOMY299, Bouéni Bay, Mayotte); h knobby colony at 35 m (IRD HS2868 Prony Bay, New Caledonia).

Fig. 2 Maps showing the localities where Madracis specimens examined in this study were sampled in the Caribbean, Southern Red Sea and Indo-Pacific (a) and in the West Atlantic, Mediterranean Sea and Northern Red Sea. Numbers in the white-filled circles indicate the sampling localities: 1, Curaçao, Dutch Caribbean; 2, Santa Maria Island, Azores; 3, La Ciotat, France; 4, Port-Cros, France; 5, Bergeggi, Italy; 6, Paraggi, Italy; 7, Zembra Island, Tunisia; 8, Taormina, Italy; 9, Kotor, Montenegro; 10, Therasia Island, Greece; 11, Yambu, Saudi Arabia; 12, Farasan Banks, Saudi Arabia; 13, Socotra Island, Yemen; 14, Mayotte Island; 15, Madang, Papua New Guinea; 16, south of the Grande Terre, New Caledonia. The color filled circles symbols indicate which species or form was sampled at each locality (brown $=M$. senaria; green $=M$. pharensis $\mathrm{f}$. luciphila , orange $=$ M. pharensis f. luciphila , turquoise $=M$. kirbyi . Further information on sampling sites in Table 1.

Fig. 3 Linear variables considered for morphological analysis of the examined Madracis species: calice diameter (CD) and inter-columellar distance (ID) (specimen PF2006.883, M. pharensis luciphila).

Fig. 4 Median-joining network of a ATP8 and b ITS region haplotypes of $M$. pharensis (orange), $M$. pharensis f. luciphila (green), Madracis senaria (grey), M. kirbyi (blue). The circle diameter is proportional to the frequency of specimens sharing the same haplotype. The length of the branches is proportional to the number of mutation events that separates the haplotypes.

Fig. 5 SEM images of the corallites arrangement (a-d), top view (e-h) and side view (i-l) of a calice, and detail of the coenosteum ornamentation in Madracis pharensis (a, e, i, m), M. pharensis f. luciphila (b, f, j, n), M. senaria (c, g, k, o), and M. kirbyi (d, h, l, p); a, e MNHN IK 2010-784 (Therasia, Greece); b, f, j, n PF2006.884 (Curaçao, Dutch Caribbean); c, g, k, o PF2006.902 (Curaçao, Dutch Caribbean); d, h IRD HS2868 (Prony Bay, New Caledonia); i MNHN IK 2010-786 (La Ciotat, France); I IRD HS672 (Banc Gail, New Caledonia); m UNIMIB MD844 (Liguria, Italy); p UNIMIB SO168 (Socotra Island, Yemen); arabic numerals on the septa in e-h indicate the cycle number; in $M$. senaria $1 \mathrm{P}$ and $1 \mathrm{M}$ indicate protosepta and 
metasepta (sensu Wells 1973b), respectively; arrows indicate the top lobe of a septum; arrowheads indicate the coenosteum ornamentation.

Fig. 6 Average ( \pm S.E.) calice diameter (CD) and inter-columellar distance (ID) for the Madracis species examined in this study. 


\section{Tables}

\section{Table 1}

List of the examined Madracis samples, including collection code, sampling locality (the number in parentheses refers to the locality shown in Fig. 1), latitude and longitude of the sampling site, expedition and collection year (Exp.), collector (Coll.) andEMBL accession numbers for the examined markers (ITS region and ATP8), and presence of morphological data (Morph.). Specimens deposited at Institut de Recherche pour le Développement, Noumea, New Caledonia (IRD); King Abdullah University of Science and Technology, Thuwal, Kingdom of Saudi Arabia (KAUST); National Museum of Natural History, Paris, France (MNHN); University of Milano-Bicocca, Milano, Italy (UNIMIB). - = sampling did not occur in the frame of any scientific expedition onboard a research vessel. Further details on the research vessels and DOI on the expeditions, when available, can be found in the acknowledgements.

\begin{tabular}{|c|c|c|c|c|c|c|c|c|c|}
\hline Species & Code & Locality & Latitude & Longitude & Exp. & Coll. & $\begin{array}{l}\text { ITS } \\
\text { region }\end{array}$ & ATP8 & Morph. \\
\hline M. pharensis & $\begin{array}{l}\text { UNIMIB } \\
\text { MD844 }\end{array}$ & Paraggi, Liguria, Italy (6) & $44^{\circ} 18.673^{\prime} \mathrm{N}$ & $9^{\circ} 12.772^{\prime} \mathrm{E}$ & -2011 & A. Caragnano & LN875783 & LN875815 & Yes \\
\hline M. pharensis & $\begin{array}{l}\text { UNIMIB } \\
\text { MD845 }\end{array}$ & Paraggi, Liguria,Italy (6) & $44^{\circ} 18.673^{\prime} \mathrm{N}$ & $9^{\circ} 12.772^{\prime} \mathrm{E}$ & -2011 & F. Benzoni & LN875784 & LN875816 & - \\
\hline M. pharensis & $\begin{array}{l}\text { UNIMIB } \\
\text { MD846 }\end{array}$ & Paraggi, Liguria,Italy (6) & $44^{\circ} 18.673^{\prime} \mathrm{N}$ & $9^{\circ} 12.772^{\prime} \mathrm{E}$ & -2011 & A. Caragnano & LN875785 & LN875817 & Yes \\
\hline M. pharensis & $\begin{array}{l}\text { UNIMIB } \\
\text { MD853 }\end{array}$ & Bergeggi, Liguria, Italy (5) & $44^{\circ} 14.047^{\prime} \mathrm{N}$ & $8^{\circ} 26.630^{\prime} \mathrm{E}$ & -2012 & S. Montano & LN875786 & LN875818 & - \\
\hline M. pharensis & $\begin{array}{l}\text { UNIMIB } \\
\text { MD856 }\end{array}$ & Taormina, Sicily, Italy (8) & $37^{\circ} 50.694^{\prime} \mathrm{N}$ & $15^{\circ} 17.943^{\prime} \mathrm{E}$ & -2012 & F. Benzoni & LN875787 & LN875819 & Yes \\
\hline M. pharensis & MD02 & Taormina, Sicily, Italy (8) & $37^{\circ} 50.694^{\prime} \mathrm{N}$ & $15^{\circ} 17.943^{\prime} \mathrm{E}$ & -2012 & F. Benzoni & - & - & Yes \\
\hline M. pharensis & MD03 & Taormina, Sicily, Italy (8) & $37^{\circ} 50.694^{\prime} \mathrm{N}$ & $15^{\circ} 17.943^{\prime} \mathrm{E}$ & -2012 & F. Benzoni & - & - & Yes \\
\hline M. pharensis & MD01 & Kotor, Montenegro (9) & $42^{\circ} 28.833^{\prime} \mathrm{N}$ & $18^{\circ} 43.267^{\prime} \mathrm{E}$ & CROMA 2014 & M. Taviani & LN875788 & LN875820 & Yes \\
\hline M. pharensis & $\begin{array}{l}\text { MNHN } \\
\text { IK2010.783 }\end{array}$ & $\begin{array}{l}\text { Pointe du Tuf, Port-Cros, } \\
\text { France (4) }\end{array}$ & $43^{\circ} 0.153^{\prime} \mathrm{N}$ & $6^{\circ} 24.815^{\prime} \mathrm{E}$ & -1970 & H. Zibrowius & - & - & Yes \\
\hline
\end{tabular}




\begin{tabular}{|c|c|c|c|c|c|c|c|c|c|}
\hline M. pharensis & $\begin{array}{l}\text { MNHN } \\
\text { IK2010.784 }\end{array}$ & $\begin{array}{l}\text { Cap Tripiti, Therasia Island, } \\
\text { Greece (10) }\end{array}$ & $36^{\circ} 24.542^{\prime} \mathrm{N}$ & $25^{\circ} 21.028^{\prime} \mathrm{E}$ & MEDOR 1967 & J.G. Harmelin & - & - & Yes \\
\hline M. pharensis & $\begin{array}{l}\text { MNHN } \\
\text { IK2010.785 }\end{array}$ & $\begin{array}{l}\text { Sao Lourenco Bay, Santa } \\
\text { Maria Island, Azores (2) }\end{array}$ & $36^{\circ} 59.2911^{\prime} \mathrm{N}$ & $25^{\circ} 02.592^{\prime} \mathrm{W}$ & Bioaçores 1971 & H. Zibrowius & - & - & Yes \\
\hline M. pharensis & $\begin{array}{l}\text { MNHN } \\
\text { IK2010.786 }\end{array}$ & $\begin{array}{l}\text { Grotte des Trois Pépés, La } \\
\text { Ciotat, France (3) }\end{array}$ & $43^{\circ} 9.763^{\prime} \mathrm{N}$ & $5^{\circ} 36.042^{\prime} \mathrm{E}$ & -1991 & H. Zibrowius & - & - & Yes \\
\hline M. pharensis & $\begin{array}{l}\text { MNHN } \\
\text { IK2010.787 }\end{array}$ & Zembra Island, Tunisia (7) & $37^{\circ} 7.191{ }^{\prime} \mathrm{N}$ & $10^{\circ} 47.2477^{\prime} \mathrm{E}$ & -1969 & H. Zibrowius & - & - & Yes \\
\hline $\begin{array}{l}\text { M. pharensis } \mathrm{f} . \\
\text { luciphila }\end{array}$ & PF2005.243 & $\begin{array}{l}\text { Curaçao, Dutch Caribbean } \\
\text { (1) }\end{array}$ & & & - & P.R. Frade & - & - & Yes \\
\hline $\begin{array}{l}\text { M. pharensis } \mathrm{f} \text {. } \\
\text { luciphila }\end{array}$ & PF2005.399 & $\begin{array}{l}\text { Curaçao, Dutch Caribbean } \\
\text { (1) }\end{array}$ & & & - & P.R. Frade & LN875789 & LN875821 & Yes \\
\hline $\begin{array}{l}\text { M. pharensis } \mathrm{f} . \\
\text { luciphila }\end{array}$ & PF2005.397 & $\begin{array}{l}\text { Curaçao, Dutch Caribbean } \\
\text { (1) }\end{array}$ & & & - & P.R. Frade & LN875790 & LN875822 & Yes \\
\hline $\begin{array}{l}\text { M. pharensis } \mathrm{f} . \\
\text { luciphila }\end{array}$ & PF2005.555 & $\begin{array}{l}\text { Curaçao, Dutch Caribbean } \\
\text { (1) }\end{array}$ & & & - & P.R. Frade & - & - & Yes \\
\hline $\begin{array}{l}\text { M. pharensis } \mathrm{f} . \\
\text { luciphila }\end{array}$ & PF2006.693 & $\begin{array}{l}\text { Curaçao, Dutch Caribbean } \\
\text { (1) }\end{array}$ & & & - & P.R. Frade & LN875791 & LN875823 & - \\
\hline $\begin{array}{l}\text { M. pharensis } \mathrm{f} . \\
\text { luciphila }\end{array}$ & PF2006.694 & $\begin{array}{l}\text { Curaçao, Dutch Caribbean } \\
\text { (1) }\end{array}$ & & & - & P.R. Frade & LN875792 & LN875824 & - \\
\hline $\begin{array}{l}\text { M. pharensis } \mathrm{f} . \\
\text { luciphila }\end{array}$ & PF2006.699 & $\begin{array}{l}\text { Curaçao, Dutch Caribbean } \\
\text { (1) }\end{array}$ & & & - & P.R. Frade & LN875793 & LN875825 & - \\
\hline $\begin{array}{l}\text { M. pharensis } \mathrm{f} . \\
\text { luciphila }\end{array}$ & PF2006.705 & $\begin{array}{l}\text { Curaçao, Dutch Caribbean } \\
\text { (1) }\end{array}$ & & & - & P.R. Frade & LN875794 & LN875826 & Yes \\
\hline $\begin{array}{l}\text { M. pharensis } \mathrm{f} . \\
\text { luciphila }\end{array}$ & PF2006.711 & $\begin{array}{l}\text { Curaçao, Dutch Caribbean } \\
\text { (1) }\end{array}$ & & & - & P.R. Frade & LN875795 & LN875827 & - \\
\hline $\begin{array}{l}\text { M. pharensis } \mathrm{f} . \\
\text { luciphila }\end{array}$ & PF2006.712 & $\begin{array}{l}\text { Curaçao, Dutch Caribbean } \\
\text { (1) }\end{array}$ & & & - & P.R. Frade & LN875796 & LN875828 & Yes \\
\hline $\begin{array}{l}\text { M. pharensis } \mathrm{f} . \\
\text { luciphila }\end{array}$ & PF2006.783 & $\begin{array}{l}\text { Curaçao, Dutch Caribbean } \\
\text { (1) }\end{array}$ & & & - & P.R. Frade & LN875797 & LN875829 & Yes \\
\hline
\end{tabular}




\begin{tabular}{|c|c|c|c|c|c|c|c|c|c|}
\hline $\begin{array}{l}\text { M. pharensis } \mathrm{f} \\
\text { luciphila }\end{array}$ & PF2006.883 & $\begin{array}{l}\text { Curaçao, Dutch Caribbean } \\
\text { (1) }\end{array}$ & & & - & P.R. Frade & LN875798 & LN875830 & Yes \\
\hline $\begin{array}{l}\text { M. pharensis } \mathrm{f} . \\
\text { luciphila }\end{array}$ & PF2006.884 & $\begin{array}{l}\text { Curaçao, Dutch Caribbean } \\
\text { (1) }\end{array}$ & & & - & P.R. Frade & LN875799 & LN875831 & - \\
\hline $\begin{array}{l}\text { M. pharensis f. } \\
\text { luciphila }\end{array}$ & PF2006.914 & $\begin{array}{l}\text { Curaçao, Dutch Caribbean } \\
\text { (1) }\end{array}$ & & & - & P.R. Frade & - & - & Yes \\
\hline $\begin{array}{l}\text { M. pharensis } \mathrm{f} . \\
\text { luciphila }\end{array}$ & PF2006.936 & $\begin{array}{l}\text { Curaçao, Dutch Caribbean } \\
\text { (1) }\end{array}$ & & & - & P.R. Frade & - & - & Yes \\
\hline M. senaria & PF2005.303 & $\begin{array}{l}\text { Curaçao, Dutch Caribbean } \\
\text { (1) }\end{array}$ & & & - & P.R. Frade & - & LN875832 & Yes \\
\hline M. senaria & PF2005.510 & $\begin{array}{l}\text { Curaçao, Dutch Caribbean } \\
\text { (1) }\end{array}$ & & & - & P.R. Frade & - & LN875833 & - \\
\hline M. senaria & PF2005.543 & $\begin{array}{l}\text { Curaçao, Dutch Caribbean } \\
\text { (1) }\end{array}$ & & & - & P.R. Frade & - & LN875834 & Yes \\
\hline M. senaria & PF2005.571 & $\begin{array}{l}\text { Curaçao, Dutch Caribbean } \\
\text { (1) }\end{array}$ & & & - & P.R. Frade & - & LN875835 & Yes \\
\hline M. senaria & PF2005.572 & $\begin{array}{l}\text { Curaçao, Dutch Caribbean } \\
\text { (1) }\end{array}$ & & & - & P.R. Frade & - & LN875836 & Yes \\
\hline M. senaria & PF2006.670 & $\begin{array}{l}\text { Curaçao, Dutch Caribbean } \\
\text { (1) }\end{array}$ & & & - & P.R. Frade & - & - & Yes \\
\hline M. senaria & PF2006.901 & $\begin{array}{l}\text { Curaçao, Dutch Caribbean } \\
\text { (1) }\end{array}$ & & & - & P.R. Frade & - & LN875837 & Yes \\
\hline M. senaria & PF2006.902 & $\begin{array}{l}\text { Curaçao, Dutch Caribbean } \\
\text { (1) }\end{array}$ & & & - & P.R. Frade & - & LN875838 & Yes \\
\hline M. kirbyi & $\begin{array}{l}\text { KAUST } \\
\text { SA037 }\end{array}$ & $\begin{array}{l}\text { Dolphen Lagoon, Farasan } \\
\text { Banks, Saudi Arabia (12) }\end{array}$ & $19^{\circ} 00.320^{\prime} \mathrm{N}$ & $40^{\circ} 08.889^{\prime} \mathrm{E}$ & $\begin{array}{l}\text { KAUST } \\
\text { FARASAN } \\
\text { BIODIVERSITY } \\
2013 \\
\end{array}$ & F. Benzoni & LN875800 & LN875839 & - \\
\hline M. kirbyi & $\begin{array}{l}\text { KAUST } \\
\text { SA074 }\end{array}$ & $\begin{array}{l}\text { Ablo, Farasan Banks, Saudi } \\
\text { Arabia (12) }\end{array}$ & $18^{\circ} 39.571 ' \mathrm{~N}$ & $40^{\circ} 49.618^{\prime} \mathrm{E}$ & $\begin{array}{l}\text { KAUST } \\
\text { FARASAN } \\
\text { BIODIVERSITY } \\
2013\end{array}$ & F. Benzoni & LN875801 & LN875840 & - \\
\hline M. kirbyi & $\begin{array}{l}\text { KAUST } \\
\text { SA1181A }\end{array}$ & Yambu, Saudi Arabia (11) & $24^{\circ} 26.561^{\prime} \mathrm{N}$ & $37^{\circ} 14.860^{\prime} \mathrm{E}$ & $\begin{array}{l}\text { KAUST AQABA } \\
\text { BIODIVERSITY } \\
2013\end{array}$ & G. Paulay & LN875802 & LN875841 & - \\
\hline
\end{tabular}




\begin{tabular}{|c|c|c|c|c|c|c|c|c|c|}
\hline M. kirbyi & $\begin{array}{l}\text { KAUST } \\
\text { SA1181B }\end{array}$ & Yambu, Saudi Arabia (11) & $24^{\circ} 26.561^{\prime} \mathrm{N}$ & $37^{\circ} 14.860^{\prime} \mathrm{E}$ & $\begin{array}{l}\text { KAUST AQABA } \\
\text { BIODIVERSITY } \\
2013\end{array}$ & G. Paulay & LN875803 & LN875842 & - \\
\hline M. kirbyi & $\begin{array}{l}\text { IRD HS } \\
\text { unreg }\end{array}$ & $\begin{array}{l}\text { Prony Bay, Grande Terre, } \\
\text { New Caledonia (16) }\end{array}$ & $22^{\circ} 19.927 ' S$ & $166^{\circ} 49.806^{\prime} \mathrm{E}$ & $\begin{array}{l}\text { HYDROPRONY } \\
2011\end{array}$ & C. Payri & - & - & Yes \\
\hline M. kirbyi & IRD HS2672 & $\begin{array}{l}\text { Ilot Casy, Grande Terre, } \\
\text { New Caledonia (16) }\end{array}$ & $22^{\circ} 21.208^{\prime} \mathrm{S}$ & $166^{\circ} 50.304^{\prime} \mathrm{E}$ & -2009 & G. Lasne & - & - & Yes \\
\hline M. kirbyi & IRD HS2868 & $\begin{array}{l}\text { Prony Bay, Grande Terre, } \\
\text { New Caledonia (16) }\end{array}$ & $22^{\circ} 21.230^{\prime} \mathrm{S}$ & $166^{\circ} 49.300^{\prime} \mathrm{E}$ & -2011 & F. Benzoni & LN875804 & LN875843 & Yes \\
\hline M. kirbyi & IRD HS2977 & $\begin{array}{l}\text { Pouembout, Grande Terre, } \\
\text { New Caledonia (16) }\end{array}$ & $21^{\circ} 16.847 ' \mathrm{~S}$ & $164^{\circ} 47.081^{\prime} \mathrm{E}$ & $\begin{array}{l}\text { CORALCAL } 4 \\
2012\end{array}$ & F. Benzoni & - & - & Yes \\
\hline M. kirbyi & $\begin{array}{l}\text { UNIMIB } \\
\text { TOMY012 }\end{array}$ & $\begin{array}{l}\text { Ile Blanche, Mayotte Island } \\
\text { (14) }\end{array}$ & $12^{\circ} 42.891 ' \mathrm{~S}$ & $45^{\circ} 10.455^{\prime} \mathrm{E}$ & $\begin{array}{l}\text { TARA OCEANS } \\
2010\end{array}$ & F. Benzoni & LN875805 & LN875844 & Yes \\
\hline M. kirbyi & $\begin{array}{l}\text { UNIMIB } \\
\text { TOMY088 }\end{array}$ & $\begin{array}{l}\text { Bouény Bay, Mayotte Island } \\
\text { (14) }\end{array}$ & $12^{\circ} 54.698^{\prime} \mathrm{S}$ & $45^{\circ} 07.871^{\prime} \mathrm{E}$ & $\begin{array}{l}\text { TARA OCEANS } \\
2010\end{array}$ & F. Benzoni & LN875806 & LN875845 & Yes \\
\hline M. kirbyi & $\begin{array}{l}\text { UNIMIB } \\
\text { TOMY298 }\end{array}$ & $\begin{array}{l}\text { Bouény Bay, Mayotte Island } \\
\text { (14) }\end{array}$ & $12^{\circ} 54.698^{\prime} \mathrm{S}$ & $45^{\circ} 07.871^{\prime} \mathrm{E}$ & $\begin{array}{l}\text { TARA OCEANS } \\
2010\end{array}$ & F. Benzoni & LN875807 & LN875846 & Yes \\
\hline M. kirbyi & $\begin{array}{l}\text { UNIMIB } \\
\text { TOMY299 }\end{array}$ & $\begin{array}{l}\text { Bouény Bay, Mayotte Island } \\
\text { (14) }\end{array}$ & $12^{\circ} 54.698 ' \mathrm{~S}$ & $45^{\circ} 07.871^{\prime} \mathrm{E}$ & $\begin{array}{l}\text { TARA OCEANS } \\
2010\end{array}$ & F. Benzoni & LN875808 & LN875847 & Yes \\
\hline M. kirbyi & $\begin{array}{l}\text { UNIMIB } \\
\text { PFB024 }\end{array}$ & $\begin{array}{l}\text { Madang, Papua New Guinea } \\
\text { (15) }\end{array}$ & $5^{\circ} 11.347 ' S$ & $145^{\circ} 49.637^{\prime} \mathrm{E}$ & NIUGINI 2012 & F. Benzoni & LN875809 & LN875848 & Yes \\
\hline M. kirbyi & $\begin{array}{l}\text { UNIMIB } \\
\text { PFB242 }\end{array}$ & $\begin{array}{l}\text { Wonad Island, Madang, } \\
\text { Papua New Guinea (15) }\end{array}$ & $5^{\circ} 11.624 ' S$ & $145^{\circ} 49.5211^{\prime} \mathrm{E}$ & NIUGINI 2012 & F. Benzoni & LN875810 & LN875849 & - \\
\hline M. kirbyi & $\begin{array}{l}\text { UNIMIB } \\
\text { PFB291 }\end{array}$ & $\begin{array}{l}\text { Madang, Papua New Guinea } \\
\text { (15) }\end{array}$ & $5^{\circ} 05.020^{\prime} \mathrm{S}$ & $145^{\circ} 49.358^{\prime} \mathrm{E}$ & NIUGINI 2012 & F. Benzoni & LN875811 & LN875850 & Yes \\
\hline M. kirbyi & $\begin{array}{l}\text { UNIMIB } \\
\text { PFB363 }\end{array}$ & $\begin{array}{l}\text { Madang, Papua New Guinea } \\
\text { (15) }\end{array}$ & $5^{\circ} 06.716 \mathrm{~S}$ & $145^{\circ} 49.354^{\prime} \mathrm{E}$ & NIUGINI 2012 & F. Benzoni & LN875812 & LN875851 & Yes \\
\hline
\end{tabular}




\begin{tabular}{|l|l|l|l|l|l|l|l|l|l|}
\hline M. kirbyi & $\begin{array}{l}\text { UNIMIB } \\
\text { SO080 }\end{array}$ & $\begin{array}{l}\text { Shalintaitin, Socotra Island, } \\
\text { Yemen (13) }\end{array}$ & $12^{\circ} 40.156^{\prime} \mathrm{S}$ & $54^{\circ} 02.850^{\prime} \mathrm{E}$ & $\begin{array}{l}\text { YEMEN } \\
\text { BIODIVERSITY } \\
2010\end{array}$ & F. Benzoni & LN875813 & LN875852 & Yes \\
\hline M. kirbyi & $\begin{array}{l}\text { UNIMIB } \\
\text { SO091 }\end{array}$ & $\begin{array}{l}\text { Alamah, Socotra Island, } \\
\text { Yemen (13) }\end{array}$ & $\begin{array}{l}12^{\circ} 36.861 ' S \\
53^{\circ} 49.137^{\prime} \mathrm{E}\end{array}$ & $\begin{array}{l}\text { YEMEN } \\
\text { BIODIVERSITY } \\
2010\end{array}$ & F. Benzoni & LN875814 & LN875853 & - \\
\hline
\end{tabular}


Table 2 Average ( \pm standard deviation) calice diameter (CD) and inter-columellar distance (ID) for the Madracis species examined in this study.

\begin{tabular}{|l|l|l|l|}
\hline Species & n & CD & ID \\
\hline M. pharensis & 9 & $1.66( \pm 0.22)$ & $2.01( \pm 0.27)$ \\
\hline M. pharensis f. luciphila & 10 & $1.25( \pm 0.28)$ & $1.85( \pm 0.12)$ \\
\hline M. senaria & 7 & $1.45( \pm 0.36)$ & $2.31( \pm 0.12)$ \\
\hline M. kirbyi & 12 & $1.46( \pm 0.32)$ & $1.91( \pm 0.18)$ \\
\hline
\end{tabular}


Table 3 One-way ANOVA results for differences between the examined Madracis species $(\mathrm{Mp}=M$.

pharensis; $\mathrm{Mpl}=$ M. pharensis $\mathrm{f}$. luciphila $\mathrm{Ms}=$ M. senaria $; \mathrm{Mk}=$ M. kirbyi). $* \mathrm{P}<0.05 ; * * \mathrm{P}<0.01 ; * * * \mathrm{P}$ $<0.001 ; * * * * \mathrm{P}<0.0001 ;$ n.s., not significant.

\begin{tabular}{|c|c|c|c|c|c|c|c|c|c|c|c|c|}
\hline & \multicolumn{2}{|c|}{ Mp - Mpl } & \multicolumn{2}{|c|}{ Mp - Ms } & \multicolumn{2}{|c|}{ Mp - Mk } & \multicolumn{2}{|c|}{ Mpl - Ms } & \multicolumn{2}{|c|}{ Mpl - Mk } & \multicolumn{2}{|c|}{ Ms - Mk } \\
\hline & $\mathrm{F}$ & $\mathrm{p}$ & $\mathrm{F}$ & $\mathrm{p}$ & $\mathrm{F}$ & $\mathrm{p}$ & $\mathrm{F}$ & $\mathrm{p}$ & $\mathrm{F}$ & $\mathrm{p}$ & $\mathrm{F}$ & $\mathrm{p}$ \\
\hline CD & 27.46 & $* * * *$ & 5.01 & * & 5.98 & n.s. & 12.06 & $* *$ & 10.19 & ** & 0.00 & n.s. \\
\hline ID & 1.87 & n.s. & 4.03 & $*$ & 0.60 & n.s. & 9.01 & $* *$ & 0.28 & n.s. & 6.19 & $*$ \\
\hline
\end{tabular}


Table 4 Pair-wise comparison of genetic distance values ( $p$-distance) within (bold) and between the examined Madracis species based on mitochondrial ATP8. Values are means ( \pm standard deviation).

\begin{tabular}{|l|l|l|l|l|}
\hline & M. pharensis & $\begin{array}{l}\text { M. pharensis f. } \\
\text { luciphila }\end{array}$ & M. senaria & M. kirbyi \\
\hline M. pharensis & $\mathbf{0 . 0 0 1 3}( \pm \mathbf{0 . 0 0 0 8})$ & & & \\
\hline $\begin{array}{l}\text { M. pharensis f. } \\
\text { luciphila }\end{array}$ & $0.0321( \pm 0.0051)$ & $\mathbf{0}( \pm \mathbf{0})$ & & \\
\hline M. senaria & $0.0304( \pm 0.0051)$ & $0.0349( \pm 0.0055)$ & $\mathbf{0 . 0 0 1 9}( \pm \mathbf{0 . 0 0 0 9})$ & \\
\hline M. kirbyi & $0.0869( \pm 0.0087)$ & $0.0968( \pm 0.0086)$ & $0.0887( \pm 0.0086)$ & $\mathbf{0}( \pm \mathbf{0})$ \\
\hline
\end{tabular}


Table 5 Pair-wise comparison of genetic distance values ( $p$-distance) within (bold) and between the examined Madracis species based on the ITS region of the nuclear rDNA. Values are means $( \pm$ standard deviation).

\begin{tabular}{|c|c|c|c|c|}
\hline & M. pharensis & $\begin{array}{l}\text { M. pharensis f. } \\
\text { luciphila }\end{array}$ & M. senaria & M. kirbyi \\
\hline M. pharensis & $0.0117( \pm 0.0027)$ & & & \\
\hline $\begin{array}{l}\text { M. pharensis } \mathrm{f} . \\
\text { luciphila }\end{array}$ & $0.0181( \pm 0.0040)$ & $0.0065( \pm 0.0018)$ & & \\
\hline M. senaria & $0.0173( \pm 0.0037)$ & $0.0171( \pm 0.0039)$ & $0.0072( \pm 0.0018)$ & \\
\hline M. kirbyi & $0.0292( \pm 0.0059)$ & $0.0273( \pm 0.0055)$ & $0.0333( \pm 0.0052)$ & $0.0118( \pm 0.0029)$ \\
\hline
\end{tabular}

